\title{
EVALUASI KINERJA METODE CLUSTER ENSEMBLE DAN LATENT CLASS CLUSTERING PADA PEUBAH CAMPURAN`
}

\author{
Debora Chrisinta ${ }^{1}$, I Made Sumertajaya ${ }^{2 \ddagger}$, and Indahwati ${ }^{3}$
}

\author{
1'Department of Statistics, IPB University, Indonesia, deborachrisinta@gmail.com \\ 2Department of Statistics, IPB University, Indonesia, imsjaya.stk@gmail.com \\ ${ }^{3}$ Department of Statistics, IPB University, Indonesia, indah.stk@gmail.com \\ ‡corresponding author
}

Indonesian Journal of Statistics and Its Applications (eISSN:2599-0802) Vol 4 No 3 (2020), 448 - 461

Copyright ( 2020 Debora Chrisinta, I Made Sumertajaya, and Indahwati. This is an open-access article distributed under the Creative Commons Attribution License, which permits unrestricted use, distribution, and reproduction in any medium, provided the original work is properly cited.

\begin{abstract}
Most of the traditional clustering algorithms are designed to focus either on numeric data or on categorical data. The collected data in the real-world often contain both numeric and categorical attributes. It is difficult for applying traditional clustering algorithms directly to these kinds of data. So, the paper aims to show the best method based on the cluster ensemble and latent class clustering approach for mixed data. Cluster ensemble is a method to combine different clustering results from two subdatasets: the categorical and numerical variables. Then, clustering algorithms are designed for numerical and categorical datasets that are employed to produce corresponding clusters. On the other side, latent class clustering is a model-based clustering used for any type of data. The numbers of clusters base on the estimation of the probability model used. The best clustering method recommends LCC, which provides higher accuracy and the smallest standard deviation ratio. However, both LCC and cluster ensemble methods produce evaluation values that are not much different as the application method used potential village data in Bengkulu Province for clustering.
\end{abstract}

Keywords: clustering, cluster ensemble, LCC, mixed data, potential village data.

\section{Pendahuluan}

Penggerombolan merupakan analisis yang sering digunakan dalam mengelompokkan objek-objek berdasarkan ukuran kemiripan atau ketidakmiripan. Semakin mirip dua

\footnotetext{
*Received Jan 2020; Accepted Nov 2020; Published online on Nov 2020
} 
objek maka semakin tinggi kemungkinan berada dalam suatu gerombol. Sebaliknya, semakin berbeda karakteristik suatu objek maka kemungkinan untuk berada dalam suatu gerombol semakin kecil. Penggerombolan dapat dikatakan ideal apabila tiap objek hanya masuk atau menjadi anggota dari salah satu gerombol sehingga tidak terjadi tumpang tindih (overlapping). Kemiripan dalam gerombol hanya berlaku dalam suatu gerombol dan antar gerombol berbeda. Ukuran kemiripan tersebut dapat dilihat berdasarkan jarak antar objek dan ukuran jarak dipengaruhi oleh jenis peubah yang digunakan. Apabila tidak dipertimbangkan pemilihan ukuran jarak yang digunakan terhadap peubah yang digunakan akan menyebabkan perhitungan jarak menjadi tidak valid.

Selain ukuran jarak yang diperhatikan dalam melakukan penggerombolan, ketepatan dalam menerapkan metode juga menjadi hal yang penting. Pada dasarnya semua metode menggunakan ukuran kesamaan atau ketidaksamaan antar objek (Johnson \& Wichern, 2007). Akibatnya, penerapan metode juga memperhatikan jenis peubah yang digunakan karena objek yang akan dilakukan penggerombolan berasal dari peubah-peubah yang digunakan. Metode yang umumnya dikenal dalam proses pembentukan gerombol adalah metode hirarki (hierarchical clustering) dan metode tak berhirarki atau yang biasa dikenal dengan metode K-Means (non-hierarchical clustering). Kedua metode tersebut dapat digunakan apabila peubah bertipe numerik. Pada kenyataannya, data yang sering dijumpai ada yang mengandung peubah kategorik. Sehingga, memerlukan suatu metode penggerombolan yang tepat untuk diterapkan pada saat data yang digunakan berasal dari peubah yang berbeda yakni peubah campuran (numerik dan kategorik).

Beberapa metode yang telah dikembangkan dalam mengatasi permasalah penggerombolan pada peubah campuran adalah Latent Class Cluster (LCC), metode Gower, algoritma K-Prototypes, Two Step Cluster Analysis (TSCA), dan cluster ensemble. Latent Class Cluster (LCC) merupakan suatu teknik penggerombolan dengan peubah campuran yang diperkenalkan oleh Lazarsfeld pada tahun 1950 dengan menggunakan konsep pendugaan probabilitas posterior sebagai ukuran kemiripan objek. Sedangkan, pada tahun 1971 Gower memperkenalkan ukuran ketidakmiripan pada data campuran serta mengadopsi proses penggerombolan pada metode peubah numerik. Berbeda dengan metode Gower, algoritma K-Prototypes merupakan pengembangan dari metode K-Means pada penggunaan data dengan peubah berbeda. Selanjutnya, Chiu et al. (2001) mengembangkan metode TSCA dalam menangani penggerombolan dengan tipe skala pengukuran berbeda pula. Demikian juga dengan metode cluster ensemble yang diperkenalkan oleh Strehl \& Ghosh (2002) dalam mengelompokkan peubah campuran dengan konsep menggabungkan dua metode berbeda sesuai jenis peubah dan pada tahun 2005 dikembangkan oleh He et al. (2005).

Pada penelitian ini akan dilakukan kajian terhadap dua metode diatas yaitu cluster ensemble dan LCC terhadap data dengan jenis peubah campuran. Selanjutnya, dari kedua metode tersebut untuk melihat ketepatan penggerombolan terbaik dapat dilihat berdasarkan rasio simpangan baku dalam geombol dan antar gerombol (Bunkers et al., 1996). Semakin kecil, nilai rasionya maka suatu metode dapat dikatakan melakukan penggerombolan dengan baik. Selain rasio keragaman, akan dilihat pula akurasi metode terhadap gerombol identitas yang sudah ditentukan dari awal. Hal ini 
berguna untuk melihat apakah rasio terkecil yang diperoleh juga memberikan keakuratan terbesar.

Kedua metode diterapkan pada data simulasi hasil bangkitan sesuai sebaran masing-masing peubah untuk di perlihatkan kinerja metode terbaik. Metode terbaik yang terpilih diterapkan pada data riil, yaitu PODES (Potensi Desa) Provinsi Bengkulu untuk menggerombolokan desa/kelurahan yang ada di Provinsi Bengkulu.

\section{Metodologi}

\subsection{Bahan dan Data}

Terdapat dua jenis data yang digunakan pada penelitian ini yaitu data bangkitan (Tabel 1) dan data riil. Data bangkitan diperoleh menggunakan software $R$ versi 3.5.2 dan menggunakan dua jenis peubah (Tabel 2 dan Tabel 3). Data tersebut digunakan untuk memperoleh metode penggerombolan terbaik yang kemudian akan digunakan pada penggerombolan data riil.

Tabel 1: Jenis data bangkitan pada simulasi

\begin{tabular}{llll}
\hline $\begin{array}{l}\text { No data } \\
\text { bangkitan }\end{array}$ & $\begin{array}{l}\text { Ukuran } \\
\text { gerombol }\end{array}$ & $\begin{array}{l}\text { Nilai korelasi pada peubah } \\
\text { numerik dalam gerombol }\end{array}$ & $\begin{array}{l}\text { Ukuran } \\
\text { data }\end{array}$ \\
\hline $1-3$ & $1: 1: 1$ & $0 ; 0.3 ; 0.9$ & 150 \\
$4-6$ & $1: 1: 2$ & $0 ; 0.3 ; 0.9$ & 150 \\
$7-9$ & $1: 2: 3$ & $0 ; 0.3 ; 0.9$ & 120 \\
$10-12$ & $1: 1: 1: 1$ & $0 ; 0.3 ; 0.9$ & 100 \\
$13-15$ & $1: 1: 2: 2$ & $0 ; 0.3 ; 0.9$ & 120 \\
$16-18$ & $1: 2: 3: 4$ & $0 ; 0.3 ; 0.9$ & 100 \\
\hline
\end{tabular}

Tabel 2: Jenis peubah pertama pada simulasi (V1) dengan $\mathrm{k}=2$

\begin{tabular}{llcll}
\hline \multicolumn{3}{c}{ Numerik } & & \multicolumn{2}{c}{ Kategorik } \\
\hline Peubah & Nilai tengah & Ragam & Peubah & Peluang \\
\hline X1 & $5 ; 20 ; 30$ & 1 & X3 & $0.6 ; 0.1 ; 0.3$ \\
X2 & $10 ; 25 ; 35$ & & X4 & $0.2 ; 0.3 ; 0.4 ; 0.1$ \\
\hline
\end{tabular}

Tabel 3: Jenis peubah kedua pada simulasi (V2) dengan $\mathrm{k}=4$

\begin{tabular}{llcll}
\hline \multicolumn{3}{c}{ Numerik } & & \multicolumn{2}{c}{ Kategorik } \\
\hline Peubah & Nilai tengah & Ragam & Peubah & Peluang \\
\hline X1 & $5 ; 20 ; 30 ; 15$ & \multirow{2}{*}{1} & X3 & $0.25 ; 0.25 ; 0.25 ; 0.25$ \\
X2 & $10 ; 25 ; 35 ; 20$ & & X4 & $0.20 ; 0.30 ; 0.20 ; 0.30$ \\
\hline
\end{tabular}

Data riil yang digunakan pada penelitian ini adalah data sekunder hasil pendataan Potensi desa (PODES) Tahun 2018 yang dikumpulkan oleh Badan Pusat Statistik (BPS) dengan satuan pengamatan adalah seluruh desa dan kelurahan di Provinsi Bengkulu dengan total sebanyak 1514 desa/kelurahan dengan rincian sebanyak 1341 desa, 172 kelurahan dan 1 unit pemukiman transmigrasi di kabupaten Muko-Muko. Adapun pemilihan peubah penelitian didasarkan pada Buku Indeks Pembangunan Desa (IPD) 2018 yang meliputi 5 dimensi (Tabel 4). 
Tabel 4: Daftar peubah penelitian berdasarkan pembagian dimensi IPD.

\begin{tabular}{|c|c|c|c|}
\hline \multirow{4}{*}{\begin{tabular}{l}
\multicolumn{1}{c}{ Dimensi } \\
a. Pelayanan dasar \\
mewakili aspek \\
pelayanan guna \\
mewujudkan bagian \\
dari kebutuhan \\
dasar
\end{tabular}} & \multicolumn{2}{|r|}{ Peubah } & Jenis \\
\hline & $\mathrm{X} 1$ & $\begin{array}{l}\text { Jumlah keseluruhan } \\
\text { sarana pendidikan }\end{array}$ & Numerik \\
\hline & $\mathrm{X} 2$ & $\begin{array}{l}\text { Jumlah keseluruhan } \\
\text { sarana kesehatan }\end{array}$ & Numerik \\
\hline & $\mathrm{X3}$ & $\begin{array}{l}\text { Jumlah keseluruhan } \\
\text { tenaga kesehatan }\end{array}$ & Numerik \\
\hline \multirow{5}{*}{$\begin{array}{l}\text { b. Kondisi infrastruktur } \\
\text { mewakili kebutuhan } \\
\text { dasar dan } \\
\text { pendukung lainnya } \\
\text { terkait dengan } \\
\text { ketersediaan } \\
\text { infrastruktur } \\
\text { ekonomi, energi, air } \\
\text { bersih dan sanitasi } \\
\text { serta komunikas dan } \\
\text { informasi. }\end{array}$} & $\mathrm{X} 4$ & $\begin{array}{l}\text { Jumlah sarana dan } \\
\text { prasarana ekonomi }\end{array}$ & Numerik \\
\hline & $\mathrm{X} 13$ & $\begin{array}{l}\text { Bahan bakar } \\
\text { memasak sebagian } \\
\text { besar keluarga }\end{array}$ & $\begin{array}{ll}\text { Kategorik } \\
\text { 1. } & \text { Gas Kota } \\
\text { 2. } & \text { LPG } 3 \mathrm{~kg} \\
\text { 3. } & \mathrm{LPG}>3 \mathrm{~kg} \\
\text { 4. } & \text { Minyak tanah } \\
\text { 5. } & \text { Kayu bakar } \\
\text { 6. } & \text { Lainnya }\end{array}$ \\
\hline & $\mathrm{x} 5$ & $\begin{array}{l}\text { Jumlah keluarga } \\
\text { pengguna listrik }\end{array}$ & Numerik \\
\hline & $\mathrm{X} 14$ & $\begin{array}{l}\text { Sumber air minum } \\
\text { sebagian besar } \\
\text { keluarga }\end{array}$ & $\begin{array}{l}\text { Kategorik } \\
\text { 1. Air Kemasan bermerk } \\
\text { 2. Air isi ulang } \\
\text { 3. Ledeng dengan } \\
\text { meteran (PAM/PDAM) } \\
\text { 4. Ledeng tanpa meteran } \\
\text { 5. Sumur bor tanpa } \\
\text { pompa } \\
\text { 6. Sumur } \\
\text { 7. Mata air } \\
\text { 8. Sungai/danau/kolam/w } \\
\text { aduk/situ/embung/bend } \\
\text { ungan } \\
\text { 9. Air hujan } \\
\text { 10. Lainnya }\end{array}$ \\
\hline & $\mathrm{X} 15$ & $\begin{array}{l}\text { Sumber air } \\
\text { mandi/cuci } \\
\text { sebagian besar } \\
\text { keluarga }\end{array}$ & $\begin{array}{ll}\text { Kategorik } \\
\text { 1. } \\
\text { Ledeng dengan } \\
\text { 2. } \text { Leteran (PAM/PDAM) } \\
\text { 3. Sumur bor tanpa } \\
\text { pompa } \\
\text { 4. Sumur } \\
\text { 5. Mata air } \\
\text { 6. Sungai/danau/kolam/ } \\
\text { waduk/situ/embung/ben } \\
\text { dungan } \\
\text { 7. Air hujan } \\
\text { 8. Lainnya }\end{array}$ \\
\hline
\end{tabular}




\begin{tabular}{|c|c|c|c|}
\hline \multirow[t]{5}{*}{ Dimensi } & \multicolumn{2}{|r|}{ Peubah } & Jenis \\
\hline & $\mathrm{X} 16$ & $\begin{array}{l}\text { Kantor pos/pos } \\
\text { pembantu/rumah } \\
\text { pos }\end{array}$ & $\begin{array}{ll}\text { Kategorik } \\
\text { 1. } & \text { Beroprasi } \\
\text { 2. } & \text { Jarang beroperasi } \\
\text { 3. } & \text { Tidak beroperasi } \\
\text { 4. } & \text { Tidak ada }\end{array}$ \\
\hline & $\mathrm{X} 17$ & $\begin{array}{l}\text { Perusahaan/agen } \\
\text { jasa ekspedisi } \\
\text { (pengiriman } \\
\text { barang/dokumen) } \\
\text { swasta }\end{array}$ & $\begin{array}{ll}\text { Kategorik } \\
\text { 1. } & \text { Beroprasi } \\
\text { 2. } & \text { Jarang beroperasi } \\
\text { 3. } & \text { Tidak beroperasi } \\
\text { 4. } & \text { Tidak ada }\end{array}$ \\
\hline & $\mathrm{X} 18$ & $\begin{array}{l}\text { Fasilitas internet di } \\
\text { kantor kepala } \\
\text { desa/lurah }\end{array}$ & $\begin{array}{ll}\text { Kategorik } \\
\text { 1. } & \text { Berfungsi } \\
\text { 2. } & \text { Jarang berfungsi } \\
\text { 3. } & \text { Tidak berfungsi } \\
\text { 4. } & \text { Tidak ada }\end{array}$ \\
\hline & $\mathrm{X} 19$ & $\begin{array}{l}\text { Keberadaan warga } \\
\text { yang menggunakan } \\
\text { telepon } \\
\text { seluler/handphone }\end{array}$ & $\begin{array}{l}\text { Kategorik } \\
\text { 1. Sebagian besar warga } \\
\text { 2. Sebagian kecil warga } \\
\text { 3. Tidak ada }\end{array}$ \\
\hline $\begin{array}{l}\text { C. Aksesbilitas/ } \\
\text { Transportasi } \\
\text { meliputi akses } \\
\text { saranan dan } \\
\text { prasarana } \\
\text { transportasi yang }\end{array}$ & $\mathrm{X} 20$ & $\begin{array}{l}\text { Keberadaan } \\
\text { angkutan umum }\end{array}$ & $\begin{array}{l}\text { Kategorik } \\
\text { 1. Ada, dengan trayek } \\
\text { tetap } \\
\text { 2. Ada, tanpa trayek tetap } \\
\text { 3. Tidak ada angkutan } \\
\text { umum }\end{array}$ \\
\hline $\begin{array}{l}\text { mendukung } \\
\text { kegiatan sosial } \\
\text { ekonomi desa }\end{array}$ & $\mathrm{X} 21$ & $\begin{array}{l}\text { Jenis permukaan } \\
\text { jalan darat antar } \\
\text { desa/kelurahan } \\
\text { yang terluas }\end{array}$ & $\begin{array}{l}\text { Kategorik } \\
\text { 1. Aspal/beton } \\
\text { 2. } \text { diperkeras } \\
\text { (kerikil,batu,dll) } \\
\text { 3. Tanah } \\
\text { 4. lainnya } \\
\end{array}$ \\
\hline & $\mathrm{X} 6$ & $\begin{array}{l}\text { Waktu tempuh dari } \\
\text { kantor kepala } \\
\text { desa/lurah ke } \\
\text { kantor camat }\end{array}$ & Numerik \\
\hline & $\mathrm{X7}$ & $\begin{array}{l}\text { Biaya transportasi } \\
\text { dari kantor kepala } \\
\text { desa/lurah ke } \\
\text { kantor camat }\end{array}$ & Numerik \\
\hline & $\mathrm{X} 8$ & $\begin{array}{l}\text { Waktu tempuh dari } \\
\text { kantor kepala } \\
\text { desa/lurah ke } \\
\text { kantor } \\
\text { bupati/walikota }\end{array}$ & Numerik \\
\hline & X9 & $\begin{array}{l}\text { Biaya transportasi } \\
\text { dari kantor kepala } \\
\text { desa/lurah ke } \\
\text { kantor } \\
\text { bupati/walikota }\end{array}$ & Numerik \\
\hline
\end{tabular}




\begin{tabular}{|c|c|c|}
\hline Dimensi & Peubah & Jenis \\
\hline \multirow{3}{*}{$\begin{array}{l}\text { d. Pelayanan Umum } \\
\text { merupakan upaya } \\
\text { pemenuhan } \\
\text { kebutuhan } \\
\text { pelayanan kegiatan } \\
\text { masyarakat. Peubah } \\
\text { terpilih adalah terkait } \\
\text { dengan fasilitas } \\
\text { olahraga. }\end{array}$} & $\begin{aligned} \text { X22: } & \text { Fasilitas/lapangan } \\
& \text { olahraga Sepak } \\
& \text { bola }\end{aligned}$ & $\begin{array}{l}\text { Kategorik } \\
\text { 1. Ada, baik } \\
\text { 2. Ada, rusak parah } \\
\text { 3. Ada, rusak sedang } \\
\text { 4. } \quad \text { Tidak ada }\end{array}$ \\
\hline & $\begin{aligned} \text { X23 : Fasilitas/lapangan } \\
\\
\text { olahraga bola voli }\end{aligned}$ & $\begin{array}{l}\text { Kategorik } \\
\text { 1. Ada, baik } \\
\text { 2. Ada, rusak parah } \\
\text { 3. Ada, rusak sedang } \\
\text { 4. } \text { Tidak ada } \\
\end{array}$ \\
\hline & $\begin{aligned} \text { X24 : Fasilitas/lapangan } \\
\\
\text { olahraga bulu } \\
\\
\text { tangkis }\end{aligned}$ & $\begin{array}{l}\text { Kategorik } \\
\text { 1. Ada, baik } \\
\text { 2. Ada, rusak parah } \\
\text { 3. Ada, rusak sedang } \\
\text { 4. Tidak ada }\end{array}$ \\
\hline \multirow{3}{*}{$\begin{array}{l}\text { e. Penyelenggara } \\
\text { Pemerintahan } \\
\text { mewakili kinerja } \\
\text { pemerintahan desa } \\
\text { serta } \\
\text { pendukungnya. }\end{array}$} & $\begin{array}{l}\text { X10 : Umur Kepala desa/ } \\
\text { Lurah }\end{array}$ & Numerik \\
\hline & $\begin{aligned} \text { X11 : Umur Sekertaris } \\
\text { desa/ Lurah }\end{aligned}$ & Numerik \\
\hline & $\begin{aligned} \mathrm{X} 12: & \text { Jumlah aparatur } \\
& \text { pemerintahan desa }\end{aligned}$ & Numerik \\
\hline
\end{tabular}

\subsection{Metode Penelitian}

Adapun langkah analisis data yang dilakukan menggunakan software $\mathrm{R}$ versi 3.5.2. dalam penelitian ini adalah:

1. Menerapkan metode pada data bangkitan untuk dilakukan simulasi.

2. Penggerombolan cluster ensemble dilakukan dengan tahapan:

a. Melakukan penggerombolan menggunakan algoritma squeezer pada jenis peubah kategorik.

b. Melakukan penggerombolan pada jenis data numerik dengan metode Kmeans.

c. Mengkombinasikan hasil gerombol kategorik terhadap hasil penggerombolan data numerik dan dianggap sebagai peubah kategorik sehingga dalam melakukan penggerombolan menggunakan algoritma squeezer.

d. Menghitung rasio simpangan baku dalam gerombol dan antar gerombol dan akurasi.

3. Penggerombolan LCC dilakukan dengan tahapan:

a. Menduga parameter probbilitas posterior dengan menggunakan metode EM

b. Melakukan pengelompokan objek berdasarkan nilai probabilitas posterior yang tertinggi.

c. Menghitung rasio simpangan baku dalam gerombol dan antar gerombol dan akurasi. Rasio simpangan baku untuk peubah numerik diberikan pada persamaan berikut:

$$
S_{W}=\frac{1}{C} \sum_{c=1}^{C} S_{C} \quad \text { dan } S_{B}=\left[\frac{1}{C-1} \sum_{c=1}^{C}\left(\bar{x}_{c}-\bar{x}\right)^{2}\right]^{\frac{1}{2}}
$$

dengan,

$S_{W} \quad$ : nilai simpangan baku di dalam kelompok

$S_{B} \quad$ : nilai simpangan baku antar kelompok

$S_{C} \quad$ : nilai simpangan baku kelompok ke-c 
$\bar{x}_{c} \quad$ : rata-rata kelompok ke-c

$\bar{x} \quad$ : rata-rata keseluruhan kelompok

$C \quad$ : jumlah kelompok yang terbentuk

Sedangkan $S_{w}$ dan $S_{B}$ untuk peubah dengan tipe kategorik adalah sebagai berikut:

$$
\begin{gathered}
S_{W}=\left[\frac{1}{n-C}\left[\sum_{c=1}^{C}\left(\frac{n_{c}}{2}-\frac{1}{2 n_{c}} \sum_{k=1}^{K} n_{k c}^{2}\right)\right]\right]^{\frac{1}{2}} \text { dan } \\
S_{B}=\left[\frac{1}{C-1}\left[\frac{1}{2}\left(\sum_{c=1}^{C} \frac{1}{n_{c}} \sum_{k=1}^{K} n_{k c}^{2}\right)-\frac{1}{2 n} \sum_{k=1}^{K} n_{k}^{2}\right]\right]^{\frac{1}{2}}
\end{gathered}
$$

dimana,

$S_{W} \quad$ : nilai simpangan baku di dalam kelompok data kategorik

$S_{B} \quad$ : nilai simpangan baku antar kelompok data kategorik

$M S W \quad$ : Mean of squares within

$M S B \quad$ : Mean of squares between $c$

SSW : Sum of squares within

$S S B \quad$ : Sum of squares between

$C \quad$ : jumlah kelompok yang terbentuk

$n \quad$ : banyaknya pengamatan

$n_{k} \quad$ : jumlah pengamatan dengan kategori ke- $k$

$n_{c} \quad$ : jumlah pengamatan pada kelompok ke-c,

$n_{k c} \quad$ : jumlah pengamatan dengan kategori ke- $k$ dan kelompok ke- $c$

4. Membandingkan hasil penggerombolan antara metode cluster ensemble dan LCC dengan membandingkan nilai rasio simpangan baku dalam gerombol dan antar gerombol terkecil serta akurasi terbesar.

5. Menerapkan metode terbaik kedal data riil dan melakukan evaluasi terhadap kinerja metode terbaik terhadap keseluruhan metode sebelumnya tersebut dengan langkah sebagai berikut:

a. Melakukan eksplorasi data pada setiap peubah.

b. Melakukan penggerombolan terhadap metode terbaik yang dihasilkan pada kajian simulasi.

c. Menghitung rasio simpangan baku dalam gerombol dan antar gerombol untuk menentukan gerombol optimal.

\section{Hasil dan Pembahasan}

\subsection{Hasil Penerapan Metode pada Data Simulasi}

Metode cluster ensemble dalam melakukan penggrombolan pada data simulasi dilakukan dengan memisahkan masing-masing peubah sesuai jenisnya dan menerapkan masing-masing peubah pada metode yang sesuai. Penggerombolan peubah numerik dilakukan dengan menggunakan metode Kmeans dan peubah kategorik menggunakan algoritma squeezer. Selanjutnya pemilihan algoritma squeezer didasarkan pada penelitian $\mathrm{He}$ et al. (2005). Hasil dari tahap penggerombolan masing-masing metode tersebut diasumsikan sebagai peubah kategorik untuk kembali dilakukan penggerombolan menggunakan algoritma squeezer. 
Metode selanjutnya yang akan diterapkan dalam data simulasi adalah metode LCC, dimana proses penggerombolan dlakukan dengan mengasumsikan peubah numerik menyebar normal dan peubah kategorik menyebar multinomial. Pembentukan gerombol dengan melakukan pendugaan parameter probabilitas posterior sebagai batasan suatu objek masuk kedalam gerombol tertentu. Proses pendugaan dilakukan menggunakan algoritma Expectation Maximization (EM) diperoleh sampai pada peoses mengahasilkan dugaan yang konvergen.

Proses penerapan metode cluster ensemble dan LCC dilakukan dengan mendefinisikan banyaknya gerombol yang terbentuk pada metode sama dengan gerombol identitas yaitu 3 dan 4. Berdasarkan pengulangan sebanyak 1000 kali diperoleh hasil rasio simpangan baku dan nilai akurasi pada tiap-tiap jenis data bangkitan. Pemilihan rasio simpangan baku sebagai evaluasi kinerja metode dikarenakan semakin kecil nilai yang diperoleh memberikan makna bahwakualitas gerombol yang terbentuk semakin baik. Dengan kata lain, semakin kecil nilai rasio maka memberikan kemiripan yang semakin besar didalam gerombol dan menyebabkan semakin besar perbedaan tiap gerombol. Nilai rasio simpangan baku dihitung untuk masing-masing peubah sesuai dengan persamaan (1) dan (2). Selanjutnya dari rasio simpangan baku yang dihasilkan pada masing-masing peubah dilakukan perhitungan rata-ratanya. Proses simulasi dilakukan sebanyak 1000 kali untuk semua jenis bangkitan data, sehingga akan diperoleh 1000 nilai rasio simpangan baku. Kemudian, dari 1000 nilai tersebut dihitung kembali nilai rata-ratanya untuk digunakan sebagai perbandingan kinerja metode.

Selain rasio simpangan baku, nilai akurasi juga dipilih untuk mengevaluasi kinerja metode. Hal ini dikarenakan, data dibangkitkan sesuai karakteristik kemiripan masingmasing gerombol. Misalkan, untuk gerombol pertama pada peubah numerik pertama didefinisikan memiliki rata-rata sebesar 5 dan pada peubah numerik kedua sebesar 10 (Tabel 2). Berbeda dengan peubah numerik, peubah kategorik dibangkitkan sesuai kemunculan kategori demikian seterusnya sampai pada gerombol ketiga. Perhitungan akurasi dilakukan menggunakan tabel Confusion Matrix atau dikenal sebagai tabel ketepatan klasifikasi. Hasil penggerombolan kedua metode yang ditentukan banyaknya gerombol sesuai dengan gerombol identitas yang dibangkitkan akan dilakukan perhitungan ketepatan penggerombolannya menggunakan rumus akurasi pada Confusion Matrix. Nilai akurasi untuk satu jenis data simulasi akan diperoleh sebanyak 1000 sesuai banyaknya perulangan. Selanjutnya, seperti pada rasio simpangan baku untuk membandingkan dengan jenis data simulasi yang lain dilakukan perhitungan rata-rata terhadap nilai tersebut. Hasil proses simulasi untuk semua jenis data disajikan pada Tabel 5 berikut. Akurasi metode cluster ensemble dan Latent Class Clustering diberi simbol CE dan LCC. Rasio simpangan baku dihitung untuk gerombol identias sesuai data yang dibangkitkan dan kedua metode tersebut.

Berdasarkan Tabel 5 hasil akurasi dan rasio simpangan baku terhadap kenaikan korelasi tidak memberikan perubahan yang signifikan. Oleh karena itu, perlu adanya kajian lebih lanjut terkait hal ini. Namun, nilai yang dihasilkan kedua metode terhadap perbedaan banyaknya jenis gerombol dan rasio ukuran gerombol memberikan nilai yang konsisten. Secara keseluruhan, kedua metode memberikan nilai evaluasi yang tidak jauh berbeda. Hal ini memberikan makna bahwa kedua metode mampu melakukan penggerombolan pada peubah campuran dengan baik. Namun, apabila 
dilihat berdasarkan metode yang memberikan nilai yang terbaik paling banyak adalah metode LCC.

Tabel 5: Hasil Rataan Keseluruhan pada 1000 kali Ulangan

\begin{tabular}{lllllll}
\hline & & \multicolumn{2}{c}{ Akurasi } & \multicolumn{3}{c}{ Rasio Simpangan Baku } \\
\hline $\begin{array}{c}\text { Ukuran } \\
\text { Gerombol }\end{array}$ & $\begin{array}{c}\text { Nilai } \\
\text { Korelasi }\end{array}$ & CE & LCC & ID & CE & LCC \\
\hline \multirow{2}{*}{$1: 1: 1$} & 0 & 98.07 & 98.23 & 0.539 & 0.549 & 0.532 \\
& 0.3 & 97.98 & 98.63 & 0.539 & 0.550 & 0.512 \\
& 0.9 & 96.27 & 98.54 & 0.539 & 0.558 & 0.523 \\
\hline \multirow{3}{*}{$1: 1: 2$} & 0 & 95.87 & 98.42 & 0.632 & 0.645 & 0.637 \\
& 0.3 & 96.15 & 97.32 & 0.632 & 0.644 & 0.637 \\
& 0.9 & 95.65 & 98.21 & 0.632 & 0.647 & 0.638 \\
\hline \multirow{3}{*}{$1: 2: 3$} & 0 & 93.21 & 96.31 & 0.609 & 0.643 & 0.621 \\
& 0.3 & 93.36 & 95.55 & 0.608 & 0.643 & 0.634 \\
& 0.9 & 95.65 & 95.60 & 0.632 & 0.647 & 0.649 \\
\hline \multirow{3}{*}{$1: 1: 1: 1$} & 0 & 96.77 & 97.82 & 0.674 & 0.686 & 0.678 \\
& 0.3 & 96.44 & 97.01 & 0.675 & 0.688 & 0.682 \\
& 0.9 & 95.83 & 97.39 & 0.674 & 0.690 & 0.676 \\
\hline \multirow{3}{*}{$1: 1: 2: 2$} & 0 & 99.04 & 99.51 & 0.663 & 0.670 & 0.667 \\
& 0.3 & 98.83 & 99.78 & 0.662 & 0.670 & 0.668 \\
& 0.9 & 98.63 & 99.01 & 0.663 & 0.670 & 0.667 \\
\hline \multirow{2}{*}{$1: 2: 3: 4$} & 0 & 97.22 & 98.86 & 0.722 & 0.746 & 0.734 \\
& 0.3 & 96.92 & 97.49 & 0.722 & 0.746 & 0.742 \\
& 0.9 & 96.36 & 97.85 & 0.711 & 0.727 & 0.723
\end{tabular}

\subsection{Hasil Penerapan dan Evaluasi Metode Terbaik pada Data PODES}

Data terapan yang digunakan adalah data PODES 2018 Provinsia Bengkulu, dengan 12 peubah numerik dan 12 peubah kategorik. Dua jenis peubah ini diasumsikan mengikuti sebaran normal dan multinomial. Hal ini dikarenakan data yang ada memiliki kaakteristik parameter yang dimiliki oleh kedua sebaran tersebut. Karakteritik pada peubah numerik disajikan dengan menggunakan diagram kotak garis (boxplot). Sedangkan untuk peubah kategorik disajikan dalam presentase masing-masing kategori yang muncul, serta ada beberapa kategori dalam peubah yang tidak muncul diakibatkan adanya desa yang tidak memuat kategori tersebut. 


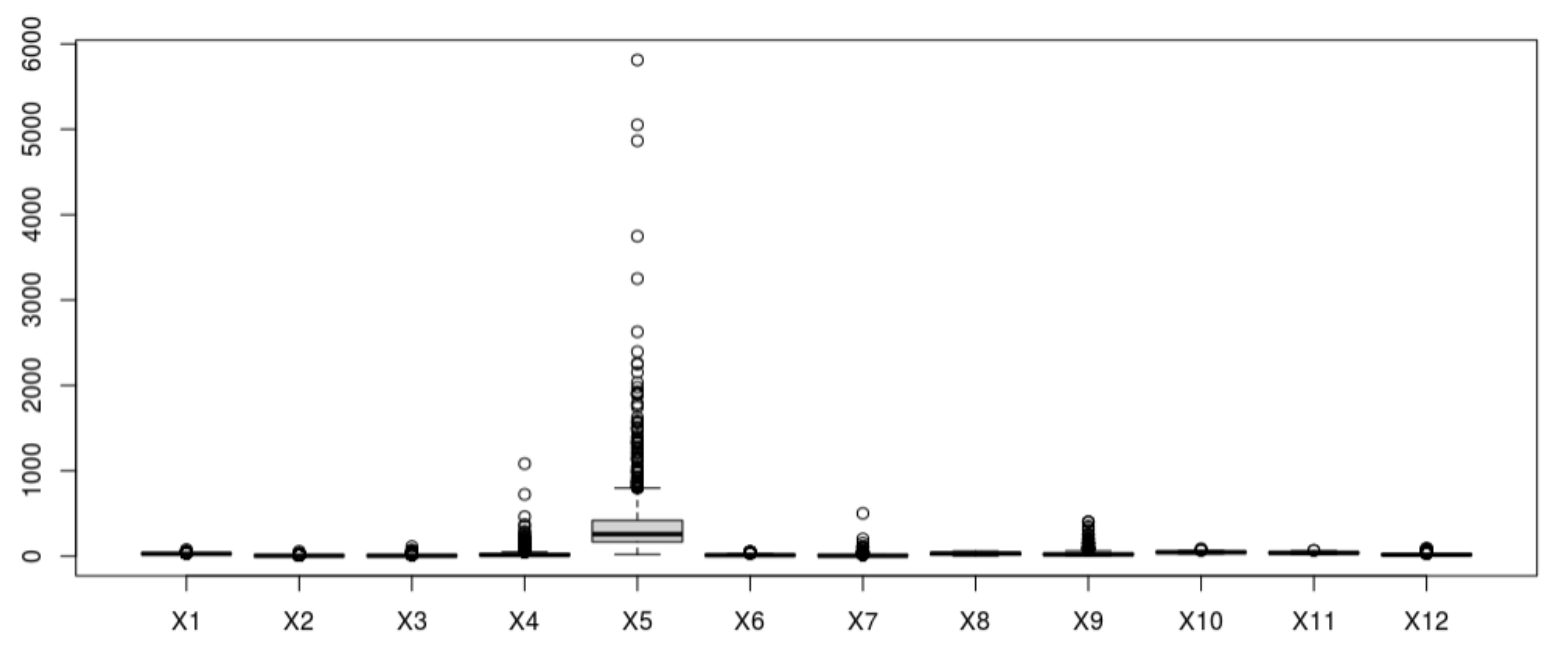

Gambar 1: Karakteristik peubah numerik data PODES.

Berdasarkan Gambar 1 peubah numerik selain X8 memiliki pencilan, dimana nilai pencilan yang diberikan terdapat dibagian atas. Pecilan tersebut merupakan nilai amatan yang lebih besar dari pada amatan lainnya. Pada peubah X5 yang merupakan banyaknya keluarga pengguna listrik memiliki sebaran nilai yang lebih besar diantara peubah yang lainnya.

Berdasarkan Gambar 2 untuk peubah kategorik diperoleh bahwa lebih dari 90\% desa menggunakan LPG $3 \mathrm{~kg}$ sebagai bahan bakar memasak dan sisanya menggunakan kayu bakar. Penggunaan air untuk minum, mandi atau mencuci lebih dari $50 \%$ desa menggunakan air sumur. Namun, melihat kondisi infrastruktur terkait keberadaan kantor pos dan agen jasa pengiriman swasta terlihat bahwa lebih dari $90 \%$ desa yang tidak memiliki infrastruktur tersebut. Hal ini berbanding terbalik dengan kondisi jalan yang sudah lebih dari $80 \%$ berbentuk aspal/beton. Ditemukan pula bahwa terdapat sekitar $60 \%$ tidak terdapat fasilitas internet di kantor desa/lurah. Lain halnya dengan kepemilikan telepon seluler bahwa terdapat lebih dari $90 \%$ desa sebagaian besar warganya telah memiliki telepon seluler. Selanjutnya, dilihat dari aspek transportasi hanya terdapat sekitar $42 \%$ desa yang memiliki angkutan umum tanpa trayek tetap. Terkait dengan keberadaan pelayanan umum dari aspek fasilitas olahraga sepak bola, bola voli dan bulu tangkis terdapat lebih dari $50 \%$ desa memiliki fasilitas tersebut.

Adapun hasil simulasi menunjukkan bahwa LCC adalah metode terbaik berdasarkan nilai rasio simpangan baku dan akurasi. Namun, pada LCC berlaku bahwa data pada peubah numerik yang digunakan harus memenuhi asumsi sebaran normal. Namu, pada saat dilakukan pengujian ternyata pada data PODES penelitian ini asumsi tersebut tidak terpenuhi. Berbagai transformasipun telah dilakukan dan memberikan hasil yang sama. Berdasarkan pertimbangan seblumnya bahwa cluster ensemble memberikan hasil yang tidak jauh berbada dengan LCC pada proses simulasi. Oleh karena itu, untuk melakukan pengerombolan pada data PODES diterapkan cluster ensemble. Tahap pertama yang dilakukan adalah menerapkan metode penggerombolan sesuai masing-masing jenis peubah, Kmeans untuk peubah numerik dan Squeezer untuk peubah kategorik. Tahap awal penggerombolan dilakukan dengan menentukan gerombol optimal. Pemilihan gerombol optimal peubah 
numerik menggunakan Package $\mathrm{R}$ NbClust dengan mendefinisikan gerombol minimun adalah 2 dan gerombol maksimum adalah 15. Hasil pemilihan gerombol terbaik berdasarkan 26 indeks. Gerombol optimal yang terbentuk adalah sebanyak 2 gerombol. Pembentukan gerombol optimal pada peubah kategorik berdasarkan nilai treshold, pemilihan berdasarkan nilai rasio simpangan baku yang terkecil. Gerombol optimal yang terbentuk adalah 2 gerombol dengan nilai treshold 3.8-4.3 karena memberikan nlai Sw/Sb terkecil.
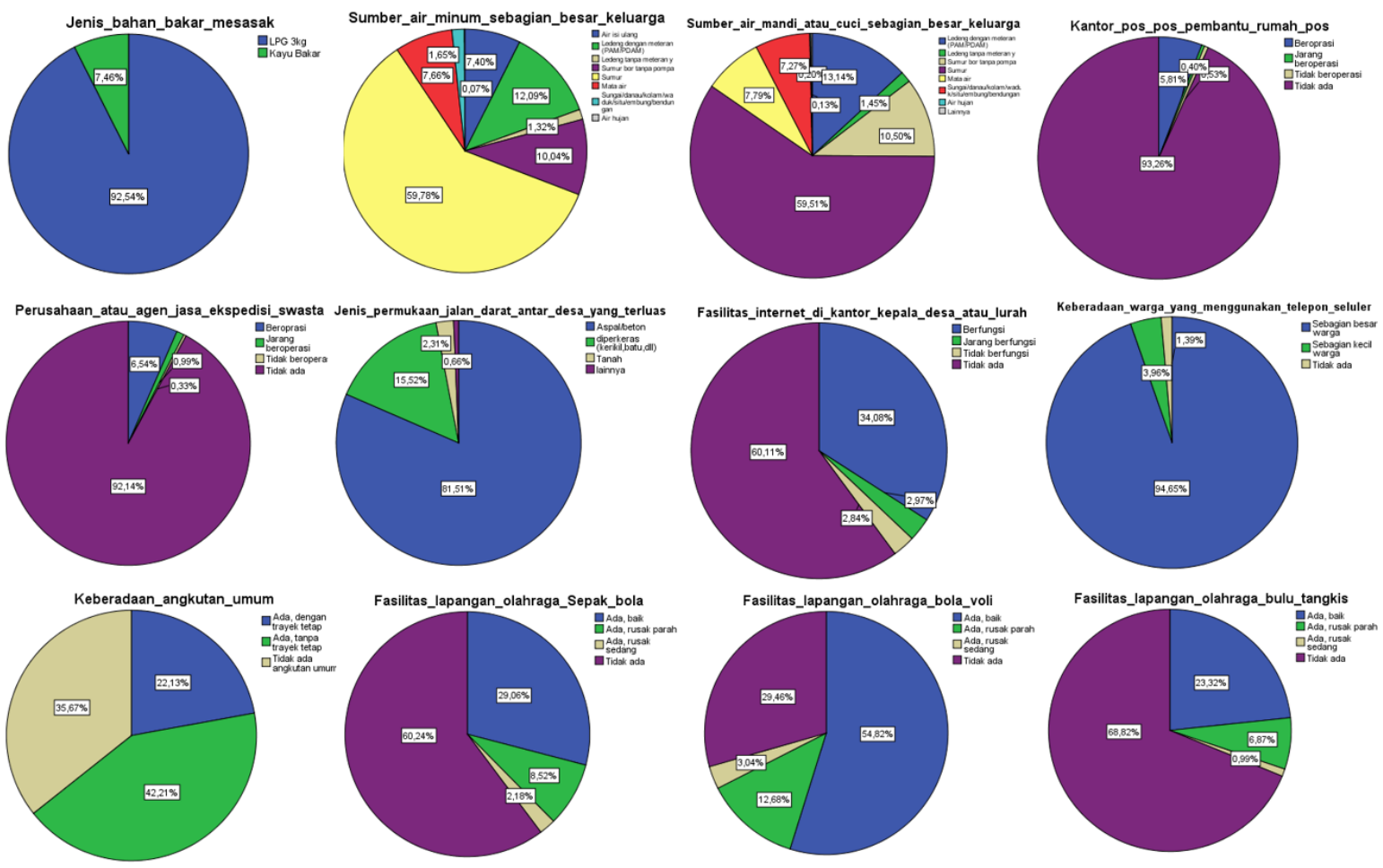

Gambar 2: Karakteristik peubah kategorik data PODES

Tahap kedua dalam cluster ensemble adalah mengasumsikan hasil penggerombolan optimum dari peubah numerik dan kategorik sebagai dua peubah kategorik baru untuk dilakukan penggerombolan menggunakan algoritma Squeezer. Hasil akhir pembentukan gerombol diperoleh berdasarkan nilai treshold yang hanya menghasilkan 3 jenis gerombol. Pemilihan gerombol optimal berdasarkan rasio simpangan baku terkecil dan gerombol optimal yang terbentuk yaitu 4 gerombol.

Visualisasi gerombol optimal untuk peubah numerik ditampilkan dalam bentuk Chernoff face, dengan memnghitung menggunakan rataan pada masing-masing peubah dalam gerombol. Deskripsi Chernoff face masing-masing peubah diberikan pada Tabel 6 berikut. 
Tabel 6: Deskripsi Ciri Wajah pada Peubah Numerik

\begin{tabular}{|c|c|c|}
\hline Peubah & Ciri Wajah & Keterangan \\
\hline $\mathrm{X} 1$ & $\begin{array}{l}\text { height of face/ } \\
\text { width of nose }\end{array}$ & $\begin{array}{l}\text { Semakin tinggi bentuk wajah/semakin lebar } \\
\text { bentuk hidung maka semakin banyak sarana } \\
\text { pendidikan }\end{array}$ \\
\hline $\mathrm{X} 2$ & $\begin{array}{l}\text { width of face / } \\
\text { width of ear }\end{array}$ & $\begin{array}{l}\text { Semakin lebar bentuk wajah/semakin lebar } \\
\text { bentuk telinga maka semakin banyak sarana } \\
\text { kesehatan }\end{array}$ \\
\hline X3 & $\begin{array}{l}\text { structure of face/ } \\
\text { height of ear }\end{array}$ & $\begin{array}{l}\text { Semakin tidak teratur bentuk wajah/semakin } \\
\text { tinggi bentuk telinga maka semakin banyak } \\
\text { pengguna listrik }\end{array}$ \\
\hline $\mathrm{X} 4$ & height of mouth & $\begin{array}{l}\text { Semakin tinggi bentuk mulut maka semakin } \\
\text { banyak aparatur desa }\end{array}$ \\
\hline $\mathrm{X} 5$ & width of mouth & $\begin{array}{l}\text { semakin lebar bentuk mulut semakin banyak } \\
\text { tenaga kesehatan } \\
\text { semakin melengkung keatas bentuk mulut }\end{array}$ \\
\hline X6 & smiling & $\begin{array}{l}\text { semakin banyak sarana dan prasarana } \\
\text { ekonomi }\end{array}$ \\
\hline $\mathrm{X} 7$ & height of eyes & $\begin{array}{l}\text { semakin tinggi bentuk mata maka semakin } \\
\text { lama waktu tempuh ke kantor camat }\end{array}$ \\
\hline $\mathrm{X} 8$ & width of eyes & $\begin{array}{l}\text { semakin lebar bentuk mata maka semakin } \\
\text { besar biaya ke kantor camat }\end{array}$ \\
\hline $\mathrm{X} 9$ & height of hair & $\begin{array}{l}\text { semakin tinggi bentuk rambut maka semakin } \\
\text { lama waktu tempuh ke kantor bupati }\end{array}$ \\
\hline $\mathrm{X} 10$ & width of hair & $\begin{array}{l}\text { semakin lebar bentuk rambut maka semakin } \\
\text { lama waktu tempuh ke kantor bupati }\end{array}$ \\
\hline $\mathrm{X} 11$ & style of hair & $\begin{array}{l}\text { semakin melengkung keatas bentuk rambut } \\
\text { maka semakin tinggi umur kades }\end{array}$ \\
\hline $\mathrm{X} 12$ & height of nose & $\begin{array}{l}\text { semakin tinggi bentuk hidung maka semakin } \\
\text { tinggi umur sekdes }\end{array}$ \\
\hline
\end{tabular}

Chernoff face dibuat dengan package aplpack pada program $\mathrm{R}$ dengan menggunakan fungsi faces (Gambar 3). Gerombol 1 dan 3 memiliki bentuk wajah yang mirip, sehingga dapat dikatakan bahwa dimensi IPD pada masing-masing peubah memiliki nilai rataan yang tidak jauh berbeda. Bentuk wajah pada gerombol 2 memiliki bentuk mulut yang paling lebar dan paling tersenyum diantara yang lainnya. Hal ini menunjukkan bahwa dimensi IPD pelayanan dasar pada aspek tenaga kesehatan dan dimensi kondisi infrastruktur aspek sarana dan prasarana ekonomi menunjukkan nilai rataan yang paling tinggi.

Bentuk ciri wajah pada Gerombol 2 menunjukkan bahwa untuk dimensi IPD pelayanan dasar aspek pendidikan, dimensi kondisi infrastruktur pada aspek penguna listrik dan dimensi penyelenggara pemerintahan untuk semua aspek memberikan nilai rataan yang paling tinggi. Hal tersebut ditunjukkan pada Gambar 3 yang menunjukkan ciri wajah yang jauh lebih menonjol dibandingkan gerombol yang lain sesuai deskripsi pada Tabel 6. Terdapat nilai rataan terkecil untuk beberapa peubah pada gerombol ini, yaitu pada dimensi aksesbilitas dan terlihat pada ciri wajah mata yang kecil serta pada tinggi dan lebar rambut yang lebih kecil dibandingkan gerombol 2. Namun hal ini, menunjukkan hal yang baik karena mengingat waktu tempuh dan biaya trasportasi 
ke kantor camat dan bupati membutuhkan waktu dan biaya yang relatif lebih murah.

1

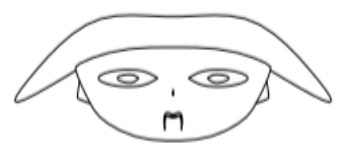

3

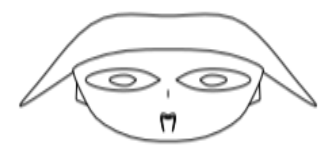

2

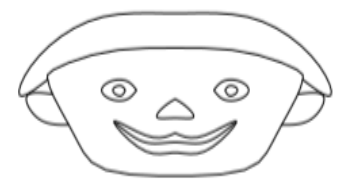

4

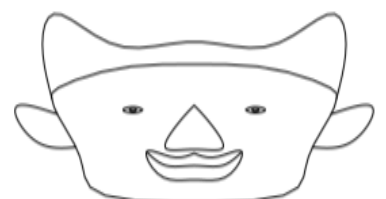

Gambar 3: Visualisasi Chernoff face pada Gerombol Terbaik Peubah Numerik

Pada peubah kategorik gerombol 1 lebih banyak didominasi oleh hampir semua kategori dalam peubah dibandingkan gerombol lain. Berdasarkan dimensi IPD untuk kondisi infrastruktur gerombol 1 memiliki karakteristik desa dengan jenis bahan bakar yang digunakan untuk memasak didominasi oleh penggunaan LPG $3 \mathrm{~kg}$ meski masih terdapat sekitar $6 \%$ dari keseluruhan desa yang masih menggunakan kayu bakar. Sumber air minum dan mandi sebagian besar keluarga pada gerombol ini paling banyak berasal dari sumur. Selain itu, mayoritas tidak tersedia infrastruktur kantor pos serta agen pengiriman barang/dokumen lainnya. Sebagian besar warga menggunakan telepon seluler meskipun masih ada warga yang tidak menggunakan telepon seluler. Berdasarkan dimensi aksesbilitas/transportasi mayoritas terdapat angkutan umum tanpa trayek tetap dan jenis permukaan jalan mayoritas berbentuk aspal/beton. Berdasarkan dimensi pelayanan umum yang terdiri dari keberadaan fasilitas olahraga antara lain lapangan sepak bola, bola voli dan bulu tangkis masih banyak desa yang tidak memiliki fasilitas tersebut.

Hasil penggerombolan akhir menunjukkan bahwa terdapat kemiripan antara gerombol 1 dan 3 serta gerombol 2 dan 4 . Hal ini dilihat berdasarkan intensitas kemunculan kategori pada masing-masing gerombol yang cenderung sama. Pada gerombol 3 memberikan tingkat IPD yang cenderung lebih tinggi dari pada gerombol 1. Dimensi IPD untuk gerombol 2 dan 4 kondisi infrastruktur memiliki karakteristik yang sama pada jenis bahan bakar memasak yaitu LPG. Dimensi pelayanan umum, transportasi/aksesbilitas dan kondisi infrastruktur terkait kepemilikan telepon seluler pada gerombol 4 hanya menampilkan satu jenis kategori yang menunjukkan IPD yang lebih baik dibandingkan gerombol laiinnya. Gerombol 2 sendiri menunjukkan IPD yang lebih baik daripada gerombol 1 dan 3 .

Secara keseluruhan berdasarkan penggerombolan cluster ensemble diperoleh bahwa tingkat IPD yang terbaik ditunjukkan pada gerombol 4 yang memuat sebanyak 4 desa yaitu desa Cempaka Permai, Panorama, Pematang Gubernur dan Bentiring Permai.

\section{Simpulan}

Secara keseluruhan hasil metode terbaik yang diperoleh pada simulasi terhadap data bangkitan adalah LCC. Namun, cluster ensemble memberikan evaluasi nilai yang tidak jauh berbeda dengan LCC. Penerapan metode terbaik pada data PODES tidak dapat 
dilakukan, karena peubah numerik pada data PODES tidak menunjukkan sebaran normal pada saat dilakukan pengujian. Oleh karena itu, menggunakan metode cluster ensemble sebagai alternatif lain yang dapat diterapkan kedalam data PODES. Gerombol optimal yang diperoleh cluster ensemble dipilih berdasarkan nilai $\mathrm{Sw} / \mathrm{Sb}$ terkecil yaitu sebanyak 4 gerombol. Peubah terpilih dalam data PODES disusun berdasarkan dimensi IPD. Hasil visualisasi gerombol optimal pada cluster ensemble menunjukkan bahwa gerombol 4 memiliki IPD terbaik dengan memuat 4 desa yaitu Cempaka Permai, Panorama, Pematang Gubernur dan Bentiring Permai.

\section{Daftar Pustaka}

Bunkers, M. J., Miller Jr, J. R., \& DeGaetano, A. T. (1996). Definition of climate regions in the Northern Plains using an objective cluster modification technique. Journal of Climate, 9(1): 130-146.

Chiu, T., Fang, D., Chen, J., Wang, Y., \& Jeris, C. (2001). A robust and scalable clustering algorithm for mixed type attributes in large database environment. Proceedings of the Seventh ACM SIGKDD International Conference on Knowledge Discovery and Data Mining, 263-268. San Francisco (US): ACM Press.

He, Z., Xu, X., \& Deng, S. (2005). Clustering mixed numeric and categorical data: A cluster ensemble approach. ArXiv Preprint Cs/0509011, 1-14.

Johnson, R. A., \& Wichern, D. W. (2007). Applied multivariate statistical analysis (Vol. 5). Prentice hall Upper Saddle River, NJ.

Strehl, A., \& Ghosh, J. (2002). Cluster ensembles-a knowledge reuse framework for combining multiple partitions. Journal of Machine Learning Research, 3(Dec): 583617. 